\title{
Quantifying hydrologic connectivity of wetlands to surface water systems
}

\author{
Ali A. Ameli and Irena F. Creed \\ Department of Biology, Western University, London, Ontario, Canada \\ Correspondence to: Irena Creed (icreed@uwo.ca)
}

Received: 10 August 2016 - Discussion started: 15 August 2016

Revised: 13 February 2017 - Accepted: 27 February 2017 - Published: 28 March 2017

\begin{abstract}
Hydrologic connectivity among wetlands is poorly characterized and understood. Our inability to quantify this connectivity compromises our understanding of the potential impacts of wetland loss on watershed structure, function and water supplies. We develop a computationally efficient, physically based subsurface-surface hydrologic model to characterize both the subsurface and surface hydrologic connectivity of "geographically isolated" wetlands and explore the time and length variations in these connections to a river within the Prairie Pothole Region of North America. Despite a high density of geographically isolated wetlands (i.e., wetlands without surface inlets or outlets), modeled connections show that these wetlands are not hydrologically isolated. Subsurface connectivity differs significantly from surface connectivity in terms of timing and length of connections. Slow subsurface connections between wetlands and the downstream river originate from wetlands throughout the watershed, whereas fast surface connections were limited to large events and originate from wetlands located near the river. This modeling approach provides first ever insight on the nature of geographically isolated wetland subsurface and surface hydrologic connections to rivers, and provides valuable information to support watershed-scale decision making for water resource management.
\end{abstract}

\section{Introduction}

Enhanced protection of wetlands is urgently needed (Dixon et al., 2016). Geographically isolated wetlands (GIWs) (Tiner, 2003) are in particular need of protection, as these are small features vulnerable to filling or drainage (Cohen et al., 2016). Geographical isolation does not imply hydro- logic, biogeochemical or biological isolation (Mushet et al., 2015; Leibowitz, 2015; Marton et al., 2015; Rains et al., 2015). Rather, GIW hydrologic connections vary in time and space, and these connections can occur through persistent but slow velocity groundwater pathways (McLaughlin and Cohen, 2013; Brannen et al., 2015; Hayashi et al., 2016) or transient but fast surface water pathways via mechanisms analogous to "fill-and-spill" runoff generation (Rains et al., 2006; Shaw et al., 2012; Leibowitz and Vining, 2003). Wetland ecosystem functions (e.g., collecting, storing, filtering or discharging water, sediments and solutes) arise from the cumulative effects of these diverse hydrologic connections (Cohen et al., 2016). For example, a lack of persistent surface connections from wetlands to rivers leads to the restriction of material and organism exchanges in landscapes; this restriction allows GIWs to influence downslope resources by enhancing flood regulation and surface water quality (Golden et al., 2014; Leibowitz, 2003; US-EPA, 2015). Subsurface connections of wetlands, on the other hand, also affect surface water resources (Cook and Hauer, 2007; Euliss et al., 2004). For example, groundwater connections between GIWs and rivers can regulate the groundwater table, stabilize base flows and change base flow chemistry (McLaughlin et al., 2014). Characterization of both surface and subsurface connections is crucial for the provision of important aquatic ecosystem services (Winter and LaBaugh, 2003).

The quantification of wetland connectivity (i.e., subsurface and surface connections among wetlands and between wetlands and rivers) remains a significant scientific challenge (US-EPA, 2015; Cohen et al., 2016; Golden et al., 2017). Our inability to quantify wetland connections compromises our understanding of (1) the role of the continuum in the timing and length of wetland connections on landscape functions; 
(2) the effects of environmental stressors (e.g., climate and land use or land cover change) on this continuum of wetland connections; and (3) the effects of human alterations of wetland connections on downstream waters. More importantly, our inability to quantify wetland connectivity may lead to inappropriate management decisions regarding wetland protection vs. removal (Van Meter and Basu, 2015). Indeed, decisions to protect or drain GIWs are often made based on their proximity to a major drainage network (Cohen et al., 2016). The quantification of wetland connectivity is required to enable prioritization of wetland protection and restoration, where the optimum location of drainage or restoration of wetlands and the hydrologic, biogeochemical and biological functions of each individual drained or restored wetland can be evaluated (Golden et al., 2017).

Effective quantification of wetland connectivity requires a modeling tool that can explicitly take into account various types (surface and subsurface) and lengths of wetland connectivity under different climate and land use or land cover scenarios. Process-based modeling tools (e.g., SWAT) are useful for assessing aggregated impacts of wetland connectivity on watershed-scale targets (e.g., watershed-scale phosphorus load or peak flow reduction) (Shrestha et al., 2012). However, these modeling tools cannot explicitly consider individual wetlands and characterize their links to other wetlands and rivers, particularly in wetland-dominated systems (Golden et al., 2014); these considerations are necessary if one intends to prioritize protection and restoration of individual wetlands (Golden et al., 2017). In contrast, numerical, physically based groundwater-surface water flow and transport modeling tools have the ability to sufficiently incorporate subsurface and surface wetland connections (Golden et al., 2014). These models, however, are typically grid based (i.e., discrete) and require high-level modeling expertise and high computational power, particularly for the simulation of watershed-scale subsurface connections. This is particularly true when these models are confronted with a range of wetland sizes; although a small subwatershed system can be discretized so that a single wetland falls within a single grid cell, incorporation of wetlands with a variety of sizes in larger wetland-dominated watersheds is challenging and prone to discretization artifacts (Golden et al., 2014). Furthermore, watershed-scale tracking of water that flows from a wetland to other local or regional surface waters within such gridbased modeling systems can be challenging and inefficient, particularly when the size of grid spacing increases to reduce computational cost (see Salamon et al., 2006).

There is currently no physically based model that adequately captures watershed-scale wetland connectivity. Recently, Ameli and Craig (2014) developed a grid-free, physically based integrated flow and transport scheme for simulation of 3-D groundwater-surface water interactions. This 3-D grid-free model is scale independent, implying that it has the potential to efficiently simulate watershed-scale (or even larger-scale) groundwater-surface water interaction and sub- surface connections among individual wetlands and between each wetland and its regional surface waters without domain discretization artifacts. Here, we use this model to map watershed-scale subsurface connections, and then link this model with a physically based transient surface flow routing simulator to map watershed-scale surface connections.

Specifically, for a large watershed dominated with GIWs within the Prairie Pothole Region (PPR) of North America, we (1) assess the performance of the 3-D groundwatersurface water interaction model at regional scales against ground-based (hydrometric, tracer, isotopic) measurements; (2) compare the distribution of time and length characteristics of simulated wetland subsurface vs. surface connections; (3) explore if the shortest distance of a wetland to other surface water bodies is an appropriate indicator of wetland connectivity; and (4) explore if our findings can be extended to the other parts of the PPR. Our wetland connectivity modeling approach fills a fundamental gap in advancing the science and management of wetland hydrologic, biogeochemical and biological connectivity in landscapes.

\section{Material and methods}

\subsection{Experimental watershed}

The Beaverhill watershed comprises $4405 \mathrm{~km}^{2}$ and is situated on the northwestern edge of the PPR (Fig. 1). The watershed is centered on the Cooking Lake moraine and drains into the North Saskatchewan River near Edmonton, Alberta, Canada. The watershed is dominated by natural forest within the moraine and agriculture (predominately grassland and pastureland) outside the moraine, with a considerable amount of urban and industrial development near the North Saskatchewan River and the city of Edmonton (Serran and Creed, 2016). The Cooking Lake moraine was recently recognized as a biosphere reserve by UNESCO, and Beaverhill Lake, located in the eastern portion of the watershed, is recognized as a wetland of international importance by the RAMSAR convention on wetlands.

The climate, geology and topography have collectively created a hydrologic system dominated by numerous lakes and wetlands as well as only a few intermittent or slowmoving streams. The climate is continental with cold winters and warm summers. Based on the 40-year (1974-2014) climatic data collected at the Edmonton International Airport, the average January temperature is $-13.5^{\circ} \mathrm{C}$ and the average July temperature is $15.9^{\circ} \mathrm{C}$ (http://climate.weather.gc.ca/). Average annual precipitation is $483 \mathrm{~mm}$, of which almost $70 \%$ falls as rain between May and September, a period when the potential evapotranspiration is as large as $450 \mathrm{~mm}$. This means that there is generally little surface runoff, although spring snowmelt can be an important contributor of local runoff to a wetland. 


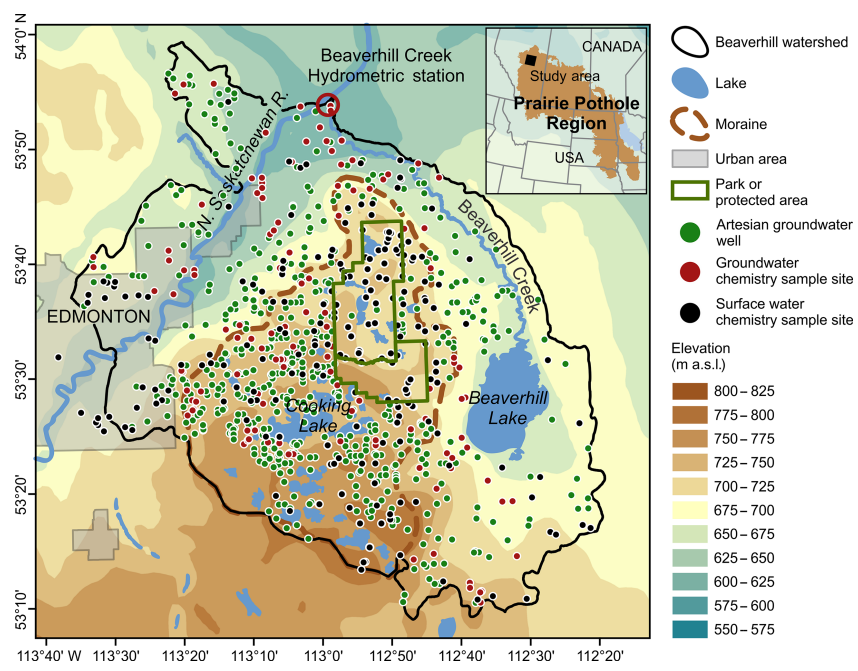

Figure 1. Beaverhill watershed, Alberta, Canada. The locations of 1413 artesian groundwater wells installed in the bedrock and screened 30 to $80 \mathrm{~m}$ below the land surface are shown (green dots). Black dots depict the locations of 208 lakes, wetlands and ponds wherein chemistry and isotopic measurements were taken. Red dots depict the locations of 121 shallow ( $<10 \mathrm{~m}$ deep) groundwater wells wherein groundwater chemistry measurements were taken. The red ring shows the location of Beaverhill Creek monitoring station. The inset shows the map of the Prairie Pothole Region of North America.

The geology is dominated by glacial deposits resulting from the Pleistocene continental glaciers. Three till sequences with variable thickness were left as a result of the last glaciation. The higher-permeability shallow till often extends from the land surface down to below the average position of the water table. For example, within the St. Denis National Wildlife Area located $500 \mathrm{~km}$ east of the Beaverhill watershed, van der Kamp and Hayashi (2009) reported a thickness of 4-5 $\mathrm{m}$ with an approximate range of saturated hydraulic conductivity between $2 \times 10^{-2}$ and $2 \mathrm{~m} \mathrm{~d}^{-1}$, and a saturated hydraulic conductivity of less than $2 \times 10^{-3} \mathrm{~m} \mathrm{~d}^{-1}$ below this layer. While the transmission rate of water from the shallow to deeper geological deposits is slow, the moraine still serves as an important source of groundwater recharge in the area, with the annual groundwater recharge rate within the Beaverhill moraine estimated to vary spatially from $5 \times 10^{-5}$ to $1.9 \times 10^{-4} \mathrm{~m} \mathrm{~d}^{-1}$ (Barker et al., 2011; Sass et al., 2014). The surficial bedrock geology is predominantly characterized by the Horseshoe Canyon Formation which is composed of fine to medium grained sediments, interfingered within muddy, transgressive sediments (Barker et al., 2011). The lithology of the surficial bedrock suggests that $\mathrm{Ca}$ and $\mathrm{Mg}$ are dominant weathering-derived products at the Beaverhill watershed.

The topographic relief ranges from a high of $812 \mathrm{~m}$ a.s.l. in the moraine to a low of $586 \mathrm{~m}$ a.s.l. along the North Saskatchewan River and reflects glacial depositional pro- cesses comprising knob, kettle and hummocky formations in the moraine surrounded by flat to rolling areas in lower elevations.

\subsection{Mapping wetlands}

A total of 130157 wetlands were delineated based on the assumption that there is a strong association between terrain depressions and wetland occurrence. A light detection and ranging (lidar) digital elevation model (DEM) captured in 2009 with a horizontal resolution of $3 \mathrm{~m}$ and an estimated vertical accuracy of $15 \mathrm{~cm}$ was used to map the probability of depression using the approach offered by Lindsay and Creed (2005). The depression probability map was then segmented into image objects using the multi-resolution segmentation algorithm (Baatz and Schäpe, 2000). Average depression probability values were used to classify objects as wetland or non-wetland, and adjacent classified wetland objects were dissolved into a single wetland (Serran and Creed, 2016). Note that this method delineated both potential wetlands without surface outlets (i.e., GIWs) and with surface outlets; given the sparsity of permanent streams in the watershed, most of the delineated wetlands can be considered a priori as GIWs. This is consistent with the observation of GIW predominance in the PPR (Cohen et al., 2016).

\subsection{Modeling wetland connectivity}

A 3-D steady-state groundwater-surface water interaction model was used to simulate watershed-scale subsurface flow and velocity fields as well as to calibrate the infiltration rate (Sect. 2.3.1). The mathematical formulation, solution parameters and boundary conditions used in the model, as well as the incorporation of the map of wetlands within the model algorithm, are explained in Appendix A. The calibrated infiltration rate was combined with meteorological data in a 2-D transient overland flow model to simulate surface flow routing (via a fill-and-spill mechanism) (Sect. 2.3.2). This oneway linked subsurface-surface model does not thoroughly consider the potential feedbacks from subsurface flow on surface flow routing. Finally, continuous watershed-scale maps of subsurface and surface velocity were generated and coupled with the wetland map to track water movement and to determine if water issued from an individual wetland reached a discharge surface water body (e.g., the North Saskatchewan River) via subsurface or surface pathways (Sect. 2.3.3). Note that, to characterize the map of connectivity to the North Saskatchewan River, the river boundary includes a $500 \mathrm{~m}$ buffer around the original line segment of the river which was obtained from a standard hydrography dataset. 


\subsubsection{Groundwater-surface water interaction model}

The 3-D groundwater-surface water interaction model used a free boundary condition to determine the location of the water table (Bear, 1972; Bresciani et al., 2016). This condition was iteratively imposed using a recharge-water table depth relation scheme (Ameli and Craig, 2014) that creates a spatially variable recharge rate and enables delineation of discharge areas where the water table reaches the land surface. This scheme assumed a steady-state subsurface flow and a hydraulic connection between groundwater and wetland water levels. The assumption of steady-state subsurface flow is strongly supported by empirical groundwater table observations collected from the closest piezometer at the Vegreville Environment Center station (located $15 \mathrm{~km}$ east of the Beaverhill watershed boundary), where the water table varied with a coefficient of variation of $<0.9 \%$ in 2009 (a year when observations were used to develop the steady-state groundwater-surface water interaction model), and a coefficient of variation of $4 \%$ over 32 years (August 1985-July 2016) (Fig. 2a). In another piezometer, at the Barrhead Environment Center station located $65 \mathrm{~km}$ west of the Beaverhill watershed boundary, the water table varied even less with a coefficient of variation of $\sim 0 \%$ during 2009 , and a coefficient of variation of $0.01 \%$ over 40 years (19772016) (Fig. 2b). The assumption of hydraulic connection between groundwater and wetland water levels is supported by previously reported empirical observations at the St. Denis National Wildlife Area, $500 \mathrm{~km}$ east of the Beaverhill watershed, that showed a maximum difference of less than $10 \mathrm{~cm}$ between the groundwater level at a piezometer located $7 \mathrm{~m}$ from the wetland edge and the wetland water level (van der Kamp and Hayashi, 2009).

The model was calibrated using saturated hydraulic conductivities of the two-layer unconfined aquifer and actual infiltration rate (see Appendix A for more details). The model performance was assessed for its ability to map groundwater discharge vs. recharge areas and subsurface connections using multiple lines of corroborating hydrometric, chemical and isotopic evidence. First, we compared the simulated groundwater discharge and recharge areas to one derived from hydrometric measurements. We used measurements of hydraulic heads in 1413 artesian groundwater wells installed in the bedrock and screened 30 to $80 \mathrm{~m}$ below the land surface (http://aep.alberta.ca/water/reports-data/ alberta-water-well-information-database/) and used a kriging approach to map the potentiometric surface throughout the entire watershed for summer 2009 (see Fig. 1 for the location of the artesian wells). Groundwater discharge and recharge areas are inferred as areas wherein potentiometric surface is above and below land surface, respectively (Barker et al., 2011).

Second, we determined if the simulated groundwater discharge and recharge areas had different chemical signatures. It is known that the concentration of weathering-derived products (such as $\mathrm{Ca}$ and $\mathrm{Mg}$ ), chemical measures affected by weathering processes (such as alkalinity and electric conductivity, EC) and total dissolved solids (TDSs) can be enhanced along the subsurface flow pathways as transit time, and therefore contact time with rock, increases (e.g., Burns et al., 2003; Maher and Druhan, 2014; Godsey et al., 2009; Cook and Hauer, 2007; Ameli et al., 2017). This implies that the concentration of $\mathrm{Ca}, \mathrm{Mg}$, alkalinity, EC and TDS in groundwater wells and surface water bodies (e.g., wetlands, lakes) located within discharge areas will be higher than recharge areas (Cook and Hauer, 2007; Euliss et al., 2004; Barker et al., 2011). We mapped $\mathrm{Ca}, \mathrm{Mg}$, alkalinity, EC and TDS measurements of 121 shallow ( $<10 \mathrm{~m}$ deep) groundwater wells located throughout the watershed, provided by the Alberta Water Well Information Database (Fig. 1), and for 208 surface waters including lakes and wetlands located throughout the watershed (Fig. 1) in summer 2009. For the latter, water samples were collected at a depth of $1 \mathrm{~m}$ using an integrated sampling tube at the center of small, shallow wetlands and $100 \mathrm{~m}$ from the shores of large, deep lakes. A nonparametric Wilcoxon rank sum test was used to see if $\mathrm{Ca}$, $\mathrm{Mg}$, alkalinity, EC and TDS concentrations or values were significantly different (higher) at groundwater wells and wetlands located in discharge areas compared to recharge areas based on comparing the $p$ values of the statistical tests to the significance level of 0.10 . At any $p$ values larger (smaller) than 0.10 , we accept that the concentrations at discharge and recharge areas are (are not) from distributions with equal medians.

Third, we determined if the simulated discharge and recharge surface water bodies had different isotopic signatures. It is known that ${ }^{18} \mathrm{O}$ and ${ }^{2} \mathrm{H}$ signatures vary between discharge and recharge areas; indeed, discharge waters that have more old water will have different isotopic signatures than recharge waters that have new water only, either from direct precipitation or indirect precipitation via overland flow (McGuire and McDonnell, 2006; Kirchner, 2016; McDonnell and Beven, 2014). This implies that the average isotopic concentration (ratio \%o) in discharge wetlands shows greater deviation from the average watershed concentration of surface waters than the deviation of recharge wetlands. We mapped isotopic ${ }^{18} \mathrm{O}$ and ${ }^{2} \mathrm{H}$ signatures in samples collected for the same 208 surface waters for which the chemical tracers were sampled (Fig. 1) in summer 2009 and used the Wilcoxon rank sum test to assess the potential differences in isotopic signatures between discharge and recharge wetlands.

The first line of corroborating evidence (hydrometric) was used to calibrate the groundwater-surface water interaction model, and the second and third lines of corroborating evidence (chemical and isotopic) were used to evaluate the performance of the model. 

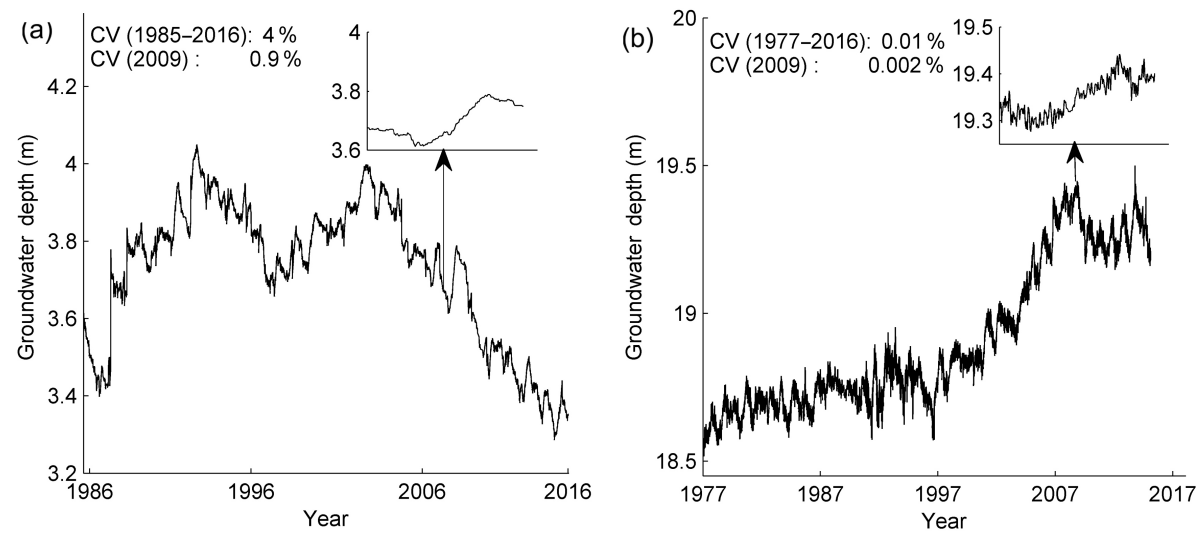

Figure 2. Observed time series of groundwater depth at two measurement stations located east and west of the Beaverhill watershed. (a) Groundwater depth from August 1985 to July 2016 at the Vegreville measurement station located $15 \mathrm{~km}$ east of the Beaverhill watershed boundary. (b) Groundwater depth from October 1977 to October 2016 at the Barrhead measurement station located $65 \mathrm{~km}$ east of the Beaverhill watershed boundary. The insets show the time series of groundwater depth in 2009 , when the observations used here to develop the steady-state groundwater-surface water interaction model were available. CV refers to the coefficient of variation of groundwater depth data during the given period.

\subsubsection{Surface fill-and-spill overland flow model}

The 2-D transient fill-and-spill surface flow routing approach within the numerical, physically based HydroGeoSphere model (Therrien et al., 2008) was used to simulate watershedscale surface water level and overland flow routing and ultimately to determine the surface connectivity of wetlands using a transient water particle tracking scheme. The 2-D surface of the watershed was discretized into 22383 grid points (43836 triangular elements). The parameters regarding time discretization were a maximum time step of $8640 \mathrm{~s}$, initial time step of $1800 \mathrm{~s}$, maximum time step multiplier of 1.5 and minimum time step multiplier of 0.5 . A critical depth boundary condition was assigned to the grid points representing the location of the Beaverhill Creek monitoring station (Fig. 1) where stream flow observations were available. A no-flow boundary condition was assigned to the watershed boundaries.

The 2-D overland flow model was calibrated using the Manning roughness coefficients (Manning et al., 1891) in $x$ and $y$ directions $\left(n_{x}\right.$ and $\left.n_{y}\right)$ as well as rill depth. The former is an empirically derived coefficient, which is dependent on surface roughness and surface cover, and the latter represents the depth that must be filled at each point before any lateral surface flow can occur. Frei and Fleckenstein (2014) suggested that the implementation of an acceptable uniform value for rill depth within the HydroGeoSphere overland flow simulator leads to an accurate prediction of watershed-scale surface flow routing. Stream flow measurements were available from 1975 to 1986 at the Beaverhill Creek monitoring station (Fig. 1). The largest runoff events when the stream flow measurements were available occurred from 1 April to 1 August 1983, and the smallest runoff events occurred from 1 April to 1 August 1985. Model calibration was conducted to match observed and simulated stream flow during the wettest period (1 April to 1 August 1983). Model validation was then conducted to match observed and simulated stream flow during the driest period (1 April to $1 \mathrm{Au}-$ gust 1985). The inputs to the models included daily precipitation, evapotranspiration (after Morton, 1978) and snow water equivalent (after Sturm et al., 2010) from data collected at the Vegreville Environment Center meteorological station ( $15 \mathrm{~km}$ east of the Beaverhill watershed boundary) as well as the steady-state infiltration rate obtained using the 3-D groundwater-surface water interaction model. We did not have access to evapotranspiration data before 2000 (including the calibration and validation periods). Instead, we used the calculated evapotranspiration time history of 2015 for the same period (1 April to 1 August 2015), because the monthly average humidity, maximum air temperature and minimum air temperature were almost similar in 1983, 1985 and 2015.

The calibrated 2-D overland flow model was then used to simulate surface flow routing from 1 April to 1 August 2009 as well as from 1 April to 1 August 2013 using meteorological data for these periods as inputs to the model. The chosen time periods include the smallest and the largest cumulative net water (precipitation minus evapotranspiration) depth observed at the Vegreville station since 2000, reflecting the minimum and maximum probability of occurrence of surface flow, and therefore surface connections, among wetlands since 2000 . Once the surface flow routing model was solved, the discretized surface water velocities in $x$ and $y$ directions at each grid point and each time step were extracted. Continuous maps of surface water velocity in $x$ and $y$ directions throughout the watershed were then approximated by interpolating the discretized surface water velocities. A Fourier-based interpolation scheme with 10000 Fourier series terms was used to complete the interpolation process 
and generate the continuous maps of surface velocity in $x$ $\left(V_{\mathrm{s}}^{x}(x, y, t)\right)$ and $y\left(V_{\mathrm{s}}^{y}(x, y, t)\right)$ directions for the entire watershed; the overall correlation coefficient between estimated velocities using the interpolation method and original modeled velocities at each grid point and time step was $r^{2}=89 \%$ $(p<0.001)$.

\subsubsection{Subsurface and surface wetland connections}

The continuous maps of subsurface steady-state $\left(V_{m}^{x}(x, y, z)\right.$, $V_{m}^{y}(x, y, z), V_{m}^{z}(x, y, z)$, Eq. A4) and transient surface velocity $\left(V_{\mathrm{s}}^{x}(x, y, t),\left(V_{\mathrm{s}}^{y}(x, y, t)\right)\right.$ were used to track water particles and generate a connectivity map using water particle tracking approach as follows.

In the subsurface domain,

$$
\begin{gathered}
x_{\mathrm{p}}(t)=x_{\mathrm{p}}(t-\Delta t)+V_{m}^{x}\left(x_{\mathrm{p}}(t-\Delta t), y_{\mathrm{p}}(t-\Delta t),\right. \\
\left.z_{\mathrm{p}}(t-\Delta t)\right) \cdot \Delta t \\
y_{\mathrm{p}}(t)=y_{\mathrm{p}}(t-\Delta t)+V_{m}^{y}\left(x_{\mathrm{p}}(t-\Delta t), y_{\mathrm{p}}(t-\Delta t),\right. \\
\left.\quad z_{\mathrm{p}}(t-\Delta t)\right) \cdot \Delta t \\
z_{\mathrm{p}}(t)=z_{\mathrm{p}}(t-\Delta t)+V_{m}^{z}\left(x_{\mathrm{p}}(t-\Delta t), y_{\mathrm{p}}(t-\Delta t),\right. \\
\left.\quad z_{\mathrm{p}}(t-\Delta t)\right) \cdot \Delta t .
\end{gathered}
$$

In the surface domain,

$$
\begin{aligned}
x_{\mathrm{p}}(t) & =x_{\mathrm{p}}(t-\Delta t)+V_{\mathrm{s}}^{x}\left(x_{\mathrm{p}}(t-\Delta t), y_{\mathrm{p}}(t-\Delta t),\right. \\
t & -\Delta t) \cdot \Delta t \\
y_{\mathrm{p}}(t) & =y_{\mathrm{p}}(t-\Delta t)+V_{\mathrm{s}}^{y}\left(x_{\mathrm{p}}(t-\Delta t), y_{\mathrm{p}}(t-\Delta t),\right. \\
t & -\Delta t) \cdot \Delta t,
\end{aligned}
$$

where $x_{\mathrm{p}}(t), y_{\mathrm{p}}(t)$ and $z_{\mathrm{p}}(t)$ are the positions of the particle $p$ at time $t$, and $x_{\mathrm{p}}(t-\Delta t), y_{\mathrm{p}}(t-\Delta t)$ and $z_{\mathrm{p}}(t-\Delta t)$ are the position of the particle $p$ at time $t-\Delta t$. In the particle tracking algorithm, a small value of the time step ( $\Delta t=0.1$ day) was assumed to ensure precise calculation of particle location and movement. A similar particle tracking method was recently used in Ameli et al. (2016a, b).

To simulate hydrologic connection among wetlands or between wetlands and the North Saskatchewan River, water particle release points in the tracking approach were placed uniformly with $500 \mathrm{~m}$ spacing along the land surface. This placement meant that there was a possibility that not all wetland connections were captured (i.e., water particle release points and small wetlands in between the $500 \mathrm{~m}$ placement would have been missed); nonetheless, it allowed for a consistent comparison of the general trend in subsurface and surface connections of wetlands. The generated connections were used to estimate subsurface and surface transit times $(\tau)$ and flowpath lengths $(l)$ that were then fitted with a gamma distribution to generate the transit time distribution $\left(\rho_{\tau}\right)$ and flowpath length distribution $\left(\rho_{l}\right)$ :

$\rho_{\tau}(\tau)=\frac{a\left(\frac{\tau}{\tau_{0}}\right)^{a-1}}{\tau_{0} \Gamma(a)} e^{-a\left(\frac{\tau}{\tau_{0}}\right)}$ and $\rho_{l}(l)=\frac{a\left(\frac{l}{l_{0}}\right)^{a-1}}{l_{0} \Gamma(a)} e^{-a\left(\frac{l}{l_{0}}\right)}$, where $\tau_{0}$ and $l_{0}$ are the mean transit time and length of hydrologic connection among wetlands or between wetlands and the North Saskatchewan River, $\Gamma(a)$ is the gamma function and $a$ is the gamma shape parameter. The time (and length) characteristics of the simulated subsurface and surface connections of wetlands were then compared.

We calculated subsurface and surface transit times and flow contributions of each wetland to the North Saskatchewan River. The relationship between distance to the river and transit times or flow contributions of wetlands can determine if distance is an effective proxy for hydrologic connectivity to the river.

The simulated subsurface connections were tested by correlating the simulated transit time of water particles discharged into discharge wetlands and the concentration of chemical tracers (Ca, Mg, EC and TDS) in the discharge wetlands. We determined if the discharge wetland which received particles with longer subsurface transit times had higher concentrations or values of $\mathrm{Ca}, \mathrm{Mg}$, alkalinity, $\mathrm{EC}$ and TDS. The pathlines (and their corresponding transit times) of water particles discharged into each discharge wetland were calculated by back tracking from 100 uniformly distributed particle release points located at each discharge wetland. The transit time corresponded to each discharge wetland was then calculated as the average of transit times of all 100 particles.

The generalizability of our findings to the entire PPR was assessed by comparing climate, geology and topography of the Beaverhill watershed to the other parts of the Prairie Pothole Region of North America. We compared monthly averaged climatic measures (including precipitation, evapotranspiration, snow water equivalent and temperature) of the Beaverhill watershed to the entire Prairie Pothole Region. We compared the average porosity and permeability of the Beaverhill watershed to the average of these measures in the entire Prairie Pothole Region. We also compared the distribution of observed shortest distances among the nearest wetland neighbors and distances between wetlands and stream networks at the Beaverhill watershed to a prairie pothole landscape in North Dakota. We obtained wetland polygons in North Dakota from the National Wetlands Inventory (https://www.fws.gov/wetlands/) and stream polylines from the National Hydrography Dataset (http://nhd.usgs.gov/). To do the latter comparison, we used a quantile-quantile plot as a graphical nonparametric method for comparing probability distributions of two unpaired samples by plotting their quantiles against each other. If the two distributions being compared are statistically similar, the theoretical line of the quantile-quantile plot will be $y=x$ and the quantile pairs will approximately lie on this line. If the distributions are not statistically similar, the theoretical line of the quantilequantile plot will be a linear line but will not follow $y=x$. 


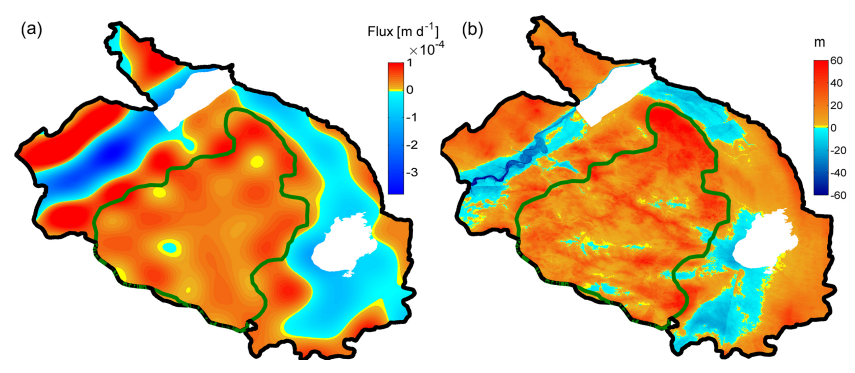

Figure 3. Comparison between simulated and inferred groundwater discharge/recharge areas. (a) Simulated groundwater discharge (blue surfaces with negative groundwater fluxes) and recharge (red surfaces with positive groundwater fluxes) areas. (b) Inferred groundwater discharge (blue surfaces) and recharge (red surfaces) areas from the potentiometric surface generated using measurements from 1413 artesian wells. Areas where the presence of the artesian wells were sparse (i.e., at the Beaverhill Lake and in the vicinity of the North Saskatchewan River; see Fig. 1) were extracted. The correlation coefficient between simulated groundwater fluxes at the land surface and the distance of potentiometric surface above and below land surface is $75 \%(p<0.001)$.

\section{Results}

\subsection{Groundwater-surface water interaction model}

The calibrated values of the saturated hydraulic conductivities are $10^{-1}$ and $10^{-3} \mathrm{~m} \mathrm{~d}^{-1}$ for the top and bottom layers, respectively. The calibrated value for infiltration rate (which here is equal to maximum groundwater recharge rate) is $1 \times 10^{-4} \mathrm{~m} \mathrm{~d}^{-1}$.

The simulated groundwater discharge/recharge map is consistent with the map of groundwater discharge/recharge inferred from measured hydraulic head (potentiometric surface) in piezometric wells (Fig. 3). Figure 3a shows the spatial distribution of groundwater discharge (negative) and recharge (positive) fluxes along the land surface obtained using the groundwater-surface water interaction model. Figure $3 b$ shows the distance of potentiometric surface from the land surface, with negative values (above land surface) representing discharge areas and positive values (below land surface) representing recharge areas, with the larger negative (or positive) values equal to larger discharge (or recharge) potential. The correlation coefficient between simulated groundwater fluxes at the land surface and the distance of potentiometric surface above and below land surface is $75 \%(p<0.001)$. Figure 3 also shows the predominance of recharge area within the moraine and the discharge area outside of the moraine.

The performance of the model was also assessed using chemical and isotopic tracer data. The concentrations or values of chemical tracers (Ca, Mg, EC and TDS) of water in shallow groundwater wells are different between the simulated discharge and recharge areas $(p<0.10)$ (Table 1a). The average concentrations of chemical tracers are higher in the simulated discharge areas than the simulated recharge areas. In addition, the concentrations or values of all chemical tracers (except $\mathrm{Mg}$ ) in simulated discharge wetlands are statistically different from simulated recharge wetlands $(p<0.10)$ (Table 1b). The average concentrations of all chemical tracers are higher in the simulated discharge wetlands than the simulated recharge wetlands. Higher concentrations of weathering products reflect the existence of longer pathlines with larger transit times within simulated discharge areas.

The average concentration of isotopic tracers $\left({ }^{18} \mathrm{O}\right.$ and $\left.{ }^{2} \mathrm{H}\right)$ in simulated discharge and recharge wetlands are significantly different $(p<0.001)$ (Table $1 \mathrm{~b})$. Also, for ${ }^{18} \mathrm{O}\left({ }^{2} \mathrm{H}\right)$, the average isotopic concentration in simulated discharge areas deviates $3 \%$ ( $8 \%$ ), whereas the average isotopic concentration in simulated recharge areas deviates only $0.9 \%$ o (3\%o) compared to the watershed average isotopic concentrations. This reflects a mixture of old and new waters in simulated discharge wetlands but mostly new waters in simulated recharge wetlands, which is consistent with our expectations.

\subsection{Surface fill-and-spill overland flow model}

The manually calibrated value of the uniformly distributed Manning roughness coefficient is $0.05 \frac{\mathrm{s}}{\mathrm{m}^{1 / 3}}$ (equal in both $x$ and $y$ directions) and the rill storage height is $0.001 \mathrm{~m}$. Figure $4 \mathrm{a}$ shows that, during the calibration period, the simulated vs. observed stream flows at the Beaverhill Creek near the mouth measurement station for the major summer rainfall period from 1 April to 1 August 1983 are significantly correlated $\left(r^{2}=0.87, p<0.001\right)$. Two statistical tests, including the Wilcoxon rank sum (equality of median) and Levene (equality of variance) tests, also suggest that the median and variance of both simulated and observed hydrographs are similar ( $p$ values are 0.44 and 0.95 , respectively). During the validation period, the simulated vs. observed stream flows at the mouth of Beaverhill Creek for the driest period (from 1 April to 1 August 1985) were also correlated $\left(r^{2}=0.45\right.$, $p<0.001$ ) (Fig. 4b). We did not expect that the surface flow model would exactly simulate the hydrograph in 1983 and 1985, as we used evapotranspiration data from 2015 for these two years (as explained in Sect. 2.3.2). This simplification could have affected the simulated hydrograph shape leading to an earlier second peak in the hydrograph of 1983 (Fig. 4a). We think this simplification would have had a minimal effect on the simulated connectivity lines, as at the end of the simulation period of 1983, the cumulative simulated flow $\left(2.4 \times 10^{7} \mathrm{~m}^{3}\right)$ at the measurement station was only $7 \%$ less than the cumulative observed flow $\left(2.6 \times 10^{7} \mathrm{~m}^{3}\right)$. Indeed, for the particle tracking scheme used to characterize the surface connectivity map, it did not make a substantial difference if the particle was at its highest velocity (e.g., 20 June vs. 24 June of 1983). Figure 4 also suggests a small contribution of base flow (almost zero from early spring to the end of June) to observed stream flow; this justifies the calibration 
Table 1. Average concentration of chemical tracers in hydrologically simulated discharge and recharge areas, as well as $p$ values of the nonparametric Wilcoxon rank sum test (equality of median) used to assess the differences between simulated groundwater discharge and recharge areas. $p$ values less than 0.10 depict a statistically significant deference between chemistry of simulated groundwater discharge and recharge areas. (a) Concentration of chemical tracers in hydrologically simulated groundwater discharge and recharge areas; (b) concentration of chemical and isotopic tracers in hydrologically simulated discharge and recharge wetlands. The reported values in the parenthesis for ${ }^{18} \mathrm{O}$ $\left(\right.$ and ${ }^{2} \mathrm{H}$ ) are the relative difference between average isotopic concentrations (ratio) in simulated discharge or recharge wetlands from average watershed concentration.

\begin{tabular}{|c|c|c|c|c|c|c|c|}
\hline (a) & & & & & & & \\
\hline & $\begin{array}{r}\mathrm{Ca} \\
\left(\mathrm{mg} \mathrm{L}^{-1}\right)\end{array}$ & $\begin{array}{r}\mathrm{Mg} \\
\left(\mathrm{mg} \mathrm{L}^{-1}\right)\end{array}$ & $\begin{array}{r}\text { TDS } \\
\left(\mathrm{mg} \mathrm{L}^{-1}\right)\end{array}$ & $\begin{array}{r}\mathrm{EC} \\
\left(\mu \mathrm{S} \mathrm{cm}^{-1}\right)\end{array}$ & & & \\
\hline Discharge & 123 & 46 & 1189 & 1631 & & & \\
\hline Recharge & 102 & 43 & 995 & 1443 & & & \\
\hline$p$ value & 0.09 & 0.02 & 0.09 & 0.05 & & & \\
\hline \multicolumn{8}{|l|}{ (b) } \\
\hline & $\begin{array}{r}\mathrm{Ca} \\
\left(\mathrm{mg} \mathrm{L}^{-1}\right)\end{array}$ & $\begin{array}{r}\mathrm{Mg} \\
\left(\mathrm{mg} \mathrm{L}^{-1}\right)\end{array}$ & $\begin{array}{r}\text { TDS } \\
\left(\mathrm{mg} \mathrm{L}^{-1}\right)\end{array}$ & $\begin{array}{r}\mathrm{EC} \\
\left(\mu \mathrm{S} \mathrm{cm}^{-1}\right)\end{array}$ & $\begin{array}{r}\text { ALK } \\
\left(\mathrm{mEqL}^{-1}\right)\end{array}$ & $\begin{array}{l}{ }^{18} \mathrm{O} \\
(\% \circ)\end{array}$ & $\begin{array}{r}{ }^{2} \mathrm{H} \\
(\% \circ)\end{array}$ \\
\hline Discharge & 65 & 42 & 1144 & 1502 & 241 & $-8.90(3)$ & $-105.37(8)$ \\
\hline Recharge & 59 & 34 & 721 & 923 & 195 & $-6.28(0.9)$ & $-91.55(3)$ \\
\hline$p$ value & 0.08 & 0.14 & 0.07 & 0.06 & 0.07 & $<0.001$ & $<0.001$ \\
\hline
\end{tabular}

Table 2. Comparison of climate and geological features between Beaverhill watershed and the entire PPR. (a) $p$ values of the Wilcoxon rank sum and Levene tests that were used to assess the similarities in median and variance, respectively, between monthly averaged climatic measures in the Beaverhill watershed and the entire PPR. These statistical analyses were conducted based on 31 years (from 1981 to 2011 ) of precipitation minus actual evapotranspiration $(P-\mathrm{ET})$, snow water equivalent (SWE) and air temperature data. $p$ values greater than 0.10 indicate a similarity between climatic measures at a significance level of 0.10 . (b) Comparison of the average values of geological features between Beaverhill watershed and the entire PPR. $\mathrm{K}\left(\mathrm{m}^{2}\right)$ refers to permeability.

\begin{tabular}{lrr}
\hline (a) & & \\
\hline & $\begin{array}{r}\text { Wilcoxon } \\
\text { rank sum }\end{array}$ & Levene \\
\hline$P-$ ET & 0.38 & 0.44 \\
SWE & 0.02 & 0.92 \\
Temperature & 0.08 & 0.19 \\
\hline (b) & & \\
\hline & PPR & Beaverhill \\
\hline Mean porosity $(\%)$ & 0.15 & 0.14 \\
Mean permeability - no permafrost $(\log (k))$ & -14.94 & -15.13 \\
Mean permeability - permafrost $(\log (k))$ & -14.94 & -15.13 \\
Mean permeability - standard deviation $\left(\mathrm{m}^{2}\right)$ & 1.79 & 1.82 \\
Bedrock geology - sedimentary rocks $(\%$ area $)$ & $96.90 \%$ & $97.67 \%$ \\
\hline
\end{tabular}

of the overland flow model with the observed stream flow at the Beaverhill Creek stream flow monitoring station.

\subsection{Wetland connectivity}

\subsubsection{Subsurface connections}

The subsurface connectivity map (Fig. 5a) indicates that recharge wetlands of a wide range of distances from the
North Saskatchewan River can be connected to the river (red lines). These wetlands range from those located in the moraine, where the length of connectivity to the river is up to $30 \mathrm{~km}$, as well as those located in the vicinity of the river, where the length of connectivity to the river is less than $5 \mathrm{~km}$. The total groundwater contribution of these recharge wetlands to the North Saskatchewan River is $0.775 \times 10^{6} \mathrm{~m}^{3}$ per month. Furthermore, water particles released from the 

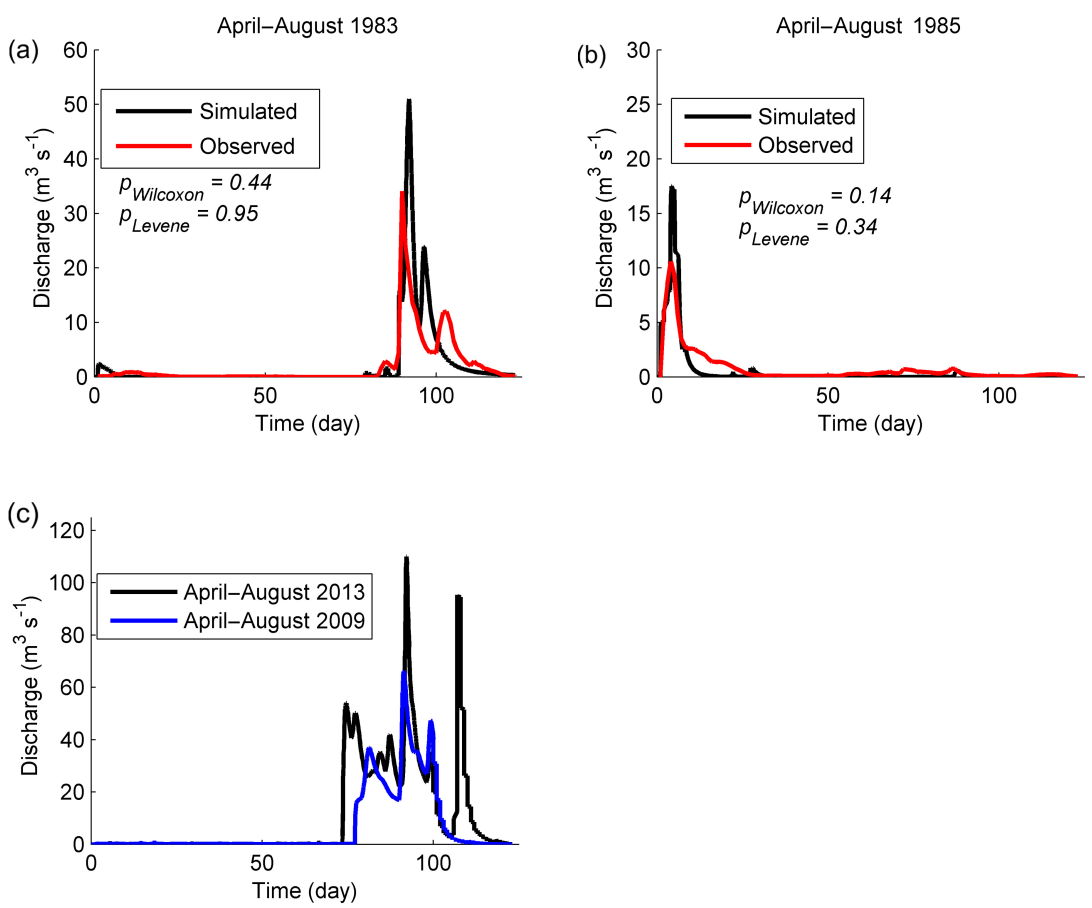

Figure 4. Simulated and observed stream flow at the Beaverhill Creek monitoring station. (a) Performance of the calibrated overland flow model in the simulation of stream flow against observed stream flow for the wettest period when the observed stream flow measurements were available from 1 April to 1 August 1983. The correlation coefficient between observed and simulated hydrographs was $87 \%(p<0.001)$. (b) Performance of the overland flow model in the validation phase for the driest period when the observed stream flow measurements were available from 1 April to 1 August 1985. The correlation coefficient between observed and simulated hydrographs was $45 \%(p<0.001)$. $P_{\text {Wilcoxon }}$ and $P_{\text {Levene }}$ refer to the $P$ values of Wilcoxon and Levene tests used to assess the similarity in median and variance between two hydrographs. (c) Simulated hydrograph from 1 April to 1 August 2013 when the largest net surface water fluxes since 2000 occurred, and from 1 April to 1 August 2009 when the smallest net surface water fluxes since 2000 occurred.

recharge wetlands located in the moraine traverse from hundreds of meters (as small as $100 \mathrm{~m}$ ) and reach discharge wetlands located in the moraine, or tens of kilometers (up to $36 \mathrm{~km}$ ) and reach Beaverhill Lake as well as discharge wetlands located outside of the moraine (blue lines). There is also a possibility for subsurface connections between recharge wetlands located at the east of the watershed to Beaverhill Lake (data not shown).

\subsubsection{Surface connections}

The North Saskatchewan River receives a majority of its wetland-originated surface waters from wetlands located in the riparian area of the river. For the period from 1 April to 1 August 2013, when the largest net surface water fluxes since 2000 occurred, the length of the surface connections to the river ranged from $50 \mathrm{~m}$ to $8 \mathrm{~km}$ (Fig. $6 \mathrm{~b}$ ), with the total surface water flow contribution from these wetlands being $1.43 \times 10^{6} \mathrm{~m}^{3}$ per month. For the period from 1 April to 1 August 2009, when the smallest net surface water fluxes since 2000 occurred, the length of the surface connections to the river ranged from $50 \mathrm{~m}$ to $3 \mathrm{~km}$ (Fig. $6 \mathrm{c}$ ), with the to- tal surface water flow contribution from these wetlands being $0.81 \times 10^{6} \mathrm{~m}^{3}$ per month.

The surface connections among wetlands within the moraine are primarily between neighboring wetlands. For the period from 1 April to 1 August 2013, the length of connection ranged from $25 \mathrm{~m}$ to $7 \mathrm{~km}$ (Fig. 6b); only one water particle released from wetlands in the moraine reached outside the moraine during this period. For the period from 1 April to 1 August 2009, the length of connection ranged from $25 \mathrm{~m}$ to $3 \mathrm{~km}$ (Fig. 6c); no water particle released from wetlands in the moraine reached outside the moraine during this period.

The modeling approach we used was a one-way linking of subsurface and surface flow processes that could not thoroughly consider the subsurface flow exfiltration feedbacks on surface flow routing. This simplification had negligible effects on wetland connectivity within the moraine, as the moraine mostly consists of recharge zones with minimum subsurface exfiltration (Fig. 3). This simplification could have affected the map of surface connectivity of wetlands located in close vicinity of the North Saskatchewan River (within a $1000 \mathrm{~m}$ buffer) wherein subsurface water can exfiltrate and enhance surface connectivity. However, the rate of subsurface exfiltration in these riparian areas was, on aver- 


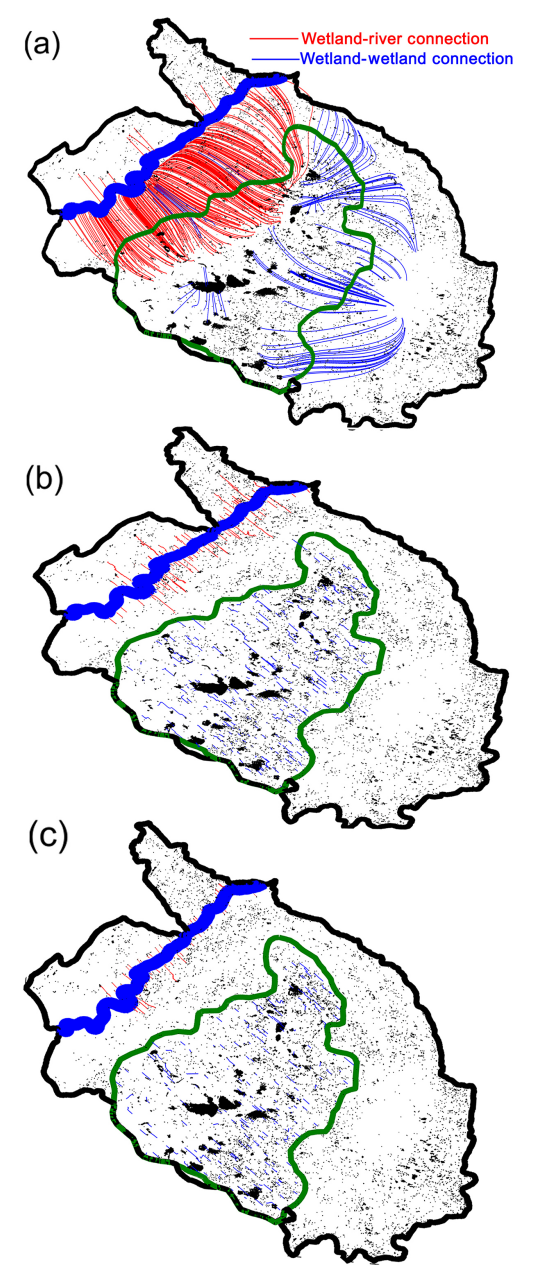

Figure 5. Hydrologic connectivity among wetlands (blue lines) and between wetlands and the North Saskatchewan River (red lines). (a) Map of subsurface connections; only particles released from recharge wetlands located in the moraine and reaching the Beaverhill Lake and discharge wetlands (blue lines) and particles discharged into the North Saskatchewan River from recharge wetlands (red lines) are shown. (b) Map of surface connections for the period from 1 April to 1 August 2013, when the largest net surface water fluxes since 2000 occurred. (c) Map of surface connections for the period from 1 April to 1 August 2009, when the smallest net surface water fluxes since 2000 occurred. Only surface connections between wetlands and the North Saskatchewan River (red lines), and connections among wetlands within the Moraine (blue lines) are shown.

age, $1 \times 10^{-4} \mathrm{~m} \mathrm{~d}^{-1}$ (Fig. 3a), which is considerably smaller than the average of net atmospheric inputs (precipitationevapotranspiration) from 1 April to 1 August 2013 that was equal to $7 \times 10^{-3} \mathrm{~m} \mathrm{~d}^{-1}$ and from 1 April to 1 August 2009 that was equal to $4 \times 10^{-3} \mathrm{~m} \mathrm{~d}^{-1}$. Therefore, while it is not known if this one-way linking simplification had negligible effects, it is unlikely that it did particularly during overland flow events.

\subsubsection{Timing and length of subsurface and surface connections}

Subsurface connections between wetlands and the North Saskatchewan River (Fig. 6a) and from wetlands located in moraine to other wetlands in the watershed (Fig. 6b) showed a significantly slower and longer timescale compared to surface connections. The average time of the subsurface connections between wetlands and the North Saskatchewan River was orders of magnitude longer than the average time of the surface connections. This difference between surface and subsurface transit times led to discontinuity in the continuum of transit times to the river as shown in Fig. 6a and b (left panel). Similarly, the average length of subsurface connections of wetlands to the North Saskatchewan River was longer than the average length of surface connections. Furthermore, among wetlands, the average of both time and length of subsurface connections were longer compared to surface connections. These discontinuities between subsurface and surface transit times (and flow lengths) may have been attributed to the lack of characterization of fast subsurface flow in our landscape and our model. Fast subsurface flow has been widely observed in humid forested landscapes with a high frequency of macropores and large hydraulic conductivities in the top-tens-of-centimeters portion of the soil. Available observations in other parts of the Canadian Prairie Pothole Region support such large shallow hydraulic conductivity (van der Kamp and Hayashi, 2009), which can lead to local fast subsurface flow connectivity among very proximal hydrologic features (as shown using the small-scale pond water budget calculation approach by Brannen et al., 2015). However, we neither have access to the observations that suggest the existence of such large shallow hydraulic conductivity in our part of the Canadian Prairie Pothole Region, nor observations that we can use to calibrate a more complex watershed-scale model which includes such small-scale heterogeneity. Inclusion of such conductive zones in our model (if such zones exist) could decrease subsurface mean transit time and mean flow length and fill the gap between surface and subsurface transit time distributions.

Figure 7 shows the relation between simulated subsurface mean transit time of particles discharged into each discharge wetland and observed concentration and values of $\mathrm{Ca}, \mathrm{Mg}$, EC and TDS of the discharge wetland. We expected that the concentration of weathering-derived products and TDS and the value of EC within discharge wetlands would be positively correlated to the subsurface mean transit time of water particles discharged into the wetland. Figure 7 shows a strong positive correlation between simulated mean transit time and the concentration or value of the different constituents within the discharge wetlands. This suggests that our simulated subsurface connectivity map and transit time are valid. 

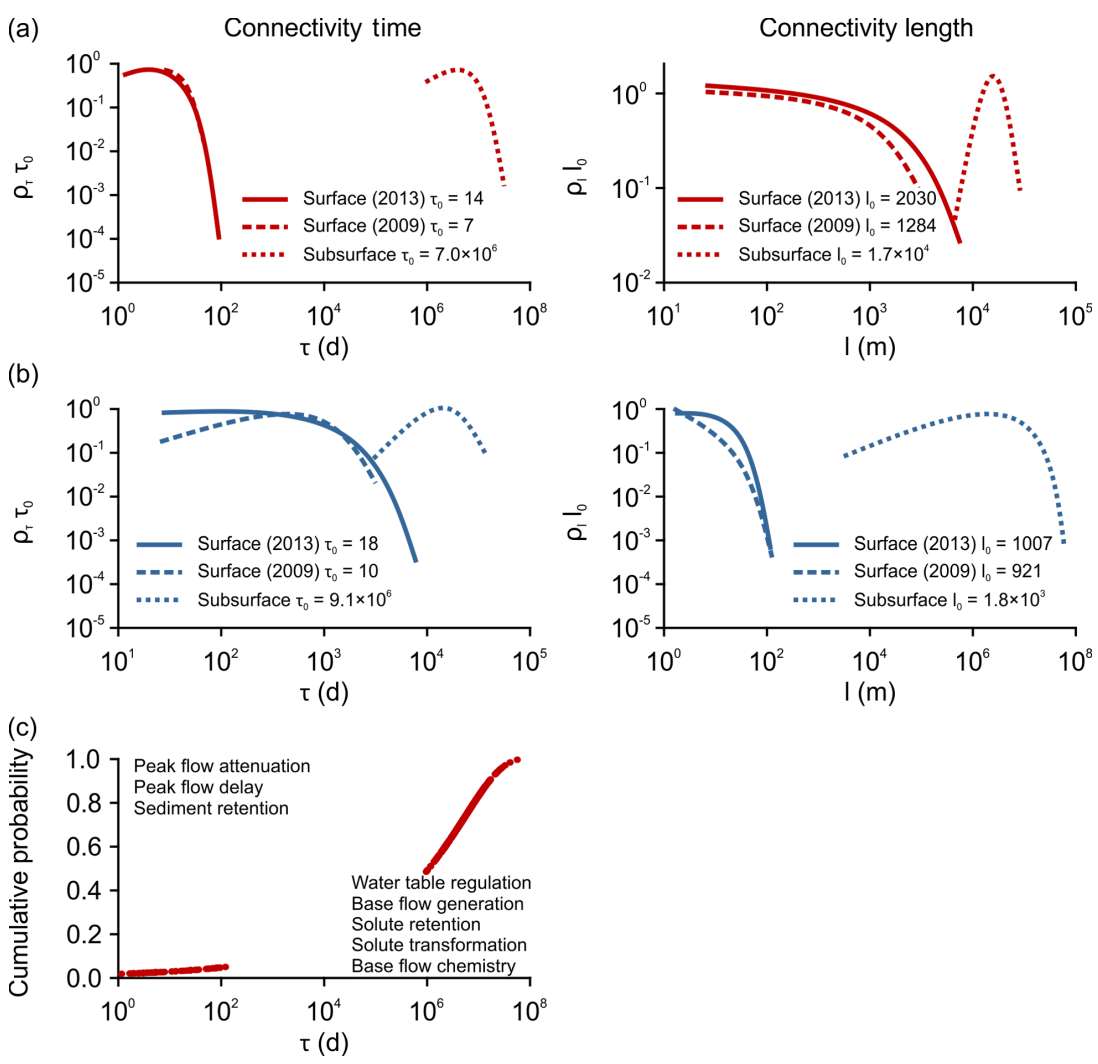

Figure 6. Fitted probability density function of subsurface or surface (both 2009 and 2013) connection transit times ( $\rho_{\tau}-$ left panel) and connection lengths $\left(\rho_{l}-\right.$ right panel) (a) between wetlands and the North Saskatchewan River and (b) from wetlands located in the moraine and other wetlands throughout the watershed. $l_{0}[\mathrm{~m}]$ and $\tau_{0}[\mathrm{~d}]$ refer to the average length and transit time, respectively. The axes labels were explained in Sect. 2.3.3 (Eq. 2). (c) Cumulative probability of transit time distribution of water particles discharged from wetlands into the North Saskatchewan River. The potential ecosystem services of each portion were also shown.

\subsubsection{Relation between wetland flow contribution to the river and wetland-river distance}

To determine whether proximity of wetlands to the North Saskatchewan River is a proxy for their hydrologic connection to the river, we calculated subsurface and surface flow contributions of each wetland to the North Saskatchewan River for a period of 4 months. The flow contributiondistance relationship of connected wetlands to the river (Fig. 8 - left panel) suggests that subsurface flow contribution of wetlands to the river is in general insensitive to their distance to the river, with a negligible correlation coefficient ( $\rho=-0.001 \%$ ) between subsurface flow contribution and distance. However, proximal wetlands contribute more surface flow to the river than distal wetlands, with a more pronounced correlation coefficient $(\rho=-15 \%)$ from 1 April to 1 August 2009, when the smallest net surface water fluxes since 2000 occurred, compared to 1 April to 1 August 2013 $(\rho=-6 \%)$, when the largest net surface water fluxes since 2000 occurred. Figure 8 (right panel) also shows that the transit time of each wetland connection to the river increases as wetland distance to the river increases; this is true for both surface and subsurface connections.

\subsection{Extendibility to the entire PPR}

Figure 9 shows that the distributions of observed shortest distance of wetlands to their nearest wetland neighbor and shortest distance of wetlands to nearest major stream are statistically similar between the Beaverhill watershed and a large portion of prairie potholes in North America (the theoretical line between distributions in the quantile-quantile plot is $x=y$ ). Table 2 a compares average monthly climatic measures in the Beaverhill watershed to the entire PPR. There is no significant difference in the median and variance of temperature between the Beaverhill watershed and the entire PPR at significance levels of 0.05 and 0.10 , respectively. There is no significant difference in the median and variance of precipitation minus evapotranspiration between the Beaverhill watershed and the entire PPR $(p>0.10)$. While there is a difference in the median snow water equivalent between the Beaverhill watershed and the entire PPR $(p<0.10)$, there is no significant difference in the variance 

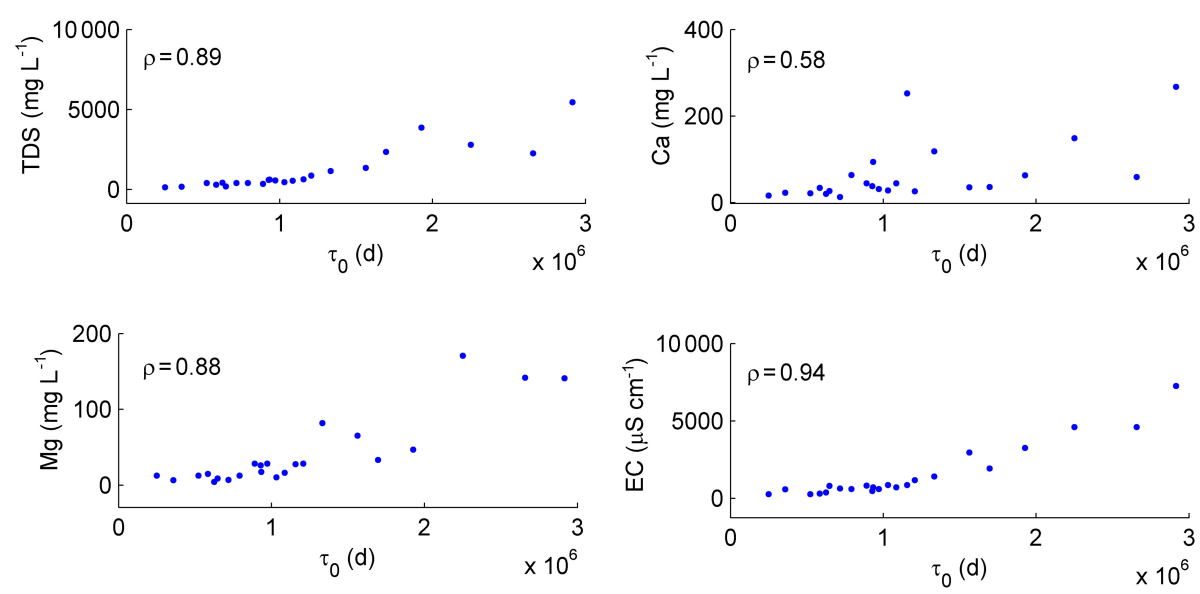

Figure 7. Relation between simulated subsurface mean transit time $\left(\tau_{0}\right)$ of each discharge wetland and the concentration of various chemical constituents in the wetland. Here, the pathlines discharged into each wetland and their associated transit times were calculated by back tracking from 100 uniformly distributed particle release points located at each discharge wetland. $\rho$ refers to the correlation coefficient between $\tau_{0}$ chemical concentrations.
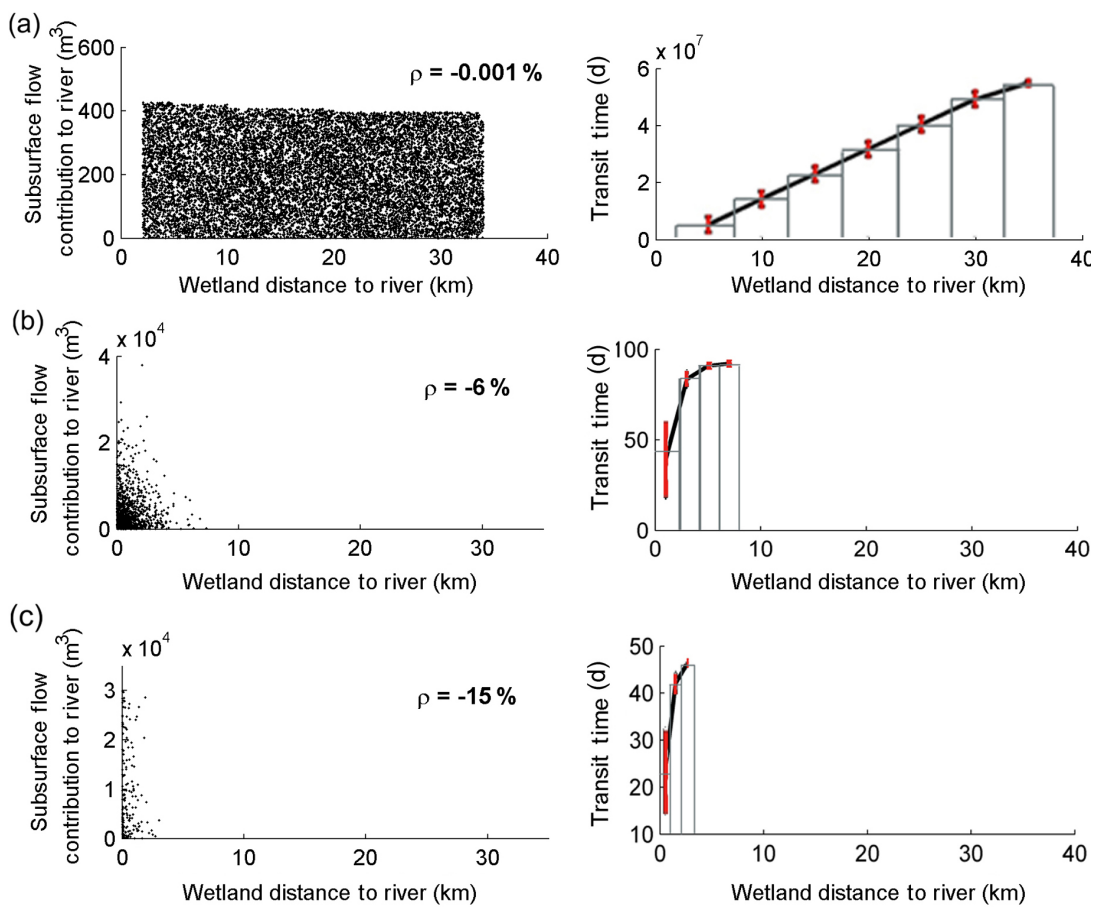

Figure 8. The relationship between flow contribution of each wetland to the North Saskatchewan River and the distance of the wetland to the North Saskatchewan River (left panel), and the relationship between transit time of connection of each wetland to the North Saskatchewan River and the distance of the wetland to the North Saskatchewan River (right panel). In the right panel, the black lines connect the mean value of each distance category and red vertical lines show the standard deviation of each category. Panel (a) shows subsurface flow contribution and connection of each wetland. Flow contribution was calculated for 4 months for each wetland using the steady-state model. Panel (b) shows surface flow contribution in 2013 and connection of each wetland. Flow contribution was calculated for 4 months (1 April to 1 August 2013) using the transient model. Panel (c) shows surface flow contribution in 2009 and connection of each wetland. Flow contribution was calculated for 4 months (1 April to 1 August 2009) using the transient model. 
of SWE ( $p=0.92$ ). The geology of the Beaverhill watershed is also consistent with the geology of the entire PPR (Table $2 \mathrm{~b}$ ). These similarities may suggest that the behavior of subsurface and surface connections of wetlands within the Beaverhill watershed can be extended to the other parts of the PPR.

\section{Discussion}

Hydrologic connectivity of wetlands determines in part their hydrologic, biogeochemical and biological functions. Hydrologic connectivity, however, is poorly understood and modeled (Cohen et al., 2016). While existing models may be able to emulate the aggregate influence of wetland connectivity on the quantity and quality of downstream waters (e.g., Shook et al., 2013), very few of these models have been designed with connectivity in mind and thus are not able to determine the local and regional interactions between wetlands and other hydrologic features in wetland-dominated landscapes.

Here, we couple a steady-state groundwater-surface water interaction model with a transient surface flow routing model to assess wetland connectivity in a large wetland-dominated watershed within the Prairie Pothole Region. The modeling approach uses a one-way linking of subsurface and surface flow processes which ignores the potential subsurface exfiltration feedback on surface flow routing. Nonetheless, the modeling approach enables answers to long-standing questions on watershed-scale surface and subsurface connections of wetlands that far outweigh its limitations.

\subsection{Model performance}

The calibrated parameters of the groundwater-surface water interaction model, including saturated hydraulic conductivities of the subsurface and recharge rate, were consistent with observations within or close to the Beaverhill watershed. The groundwater-surface water interaction model reasonably predicts groundwater discharge/recharge areas along the land surface compared to groundwater discharge/recharge areas inferred from hydraulic head measurements, chemical tracers and isotopic signatures. The fill-and-spill overland flow model predicted observed stream flow close to the Beaverhill watershed outlet with an acceptable accuracy.

\subsection{Timing and length of connection}

The model was used to map wetland connectivity and quantify the continuum of time and length variations of this connectivity. Our results reveal that wetlands in the Beaverhill watershed, with a high density of geographically isolated wetlands (GIWs), are not hydrologically isolated. Furthermore, the subsurface and surface connections show diverse amounts, timing and length. The number of wetlands connected to the major drainage network (here, the North Saskatchewan River) from subsurface pathways was signif-
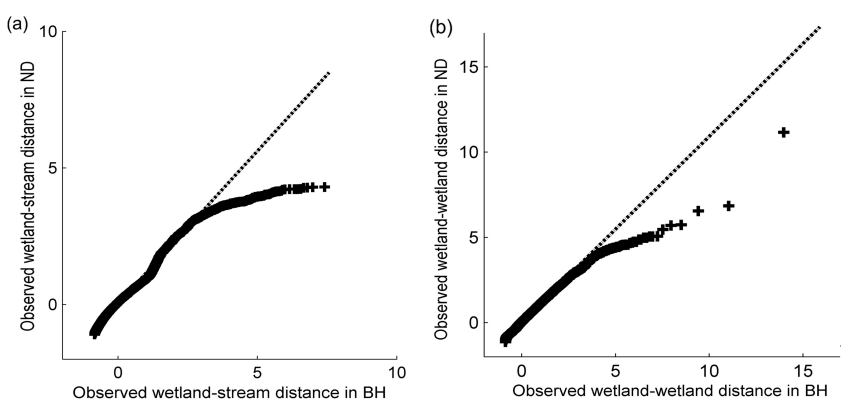

Figure 9. Quantile-quantile (Q-Q) plot comparing the distributions of observed shortest distances between surface water bodies in the Beaverhill watershed $(\mathrm{BH})$ and prairie potholes in North Dakota (ND). (a) Standardized wetland-stream distance (observed shortest distances of wetland to nearest major stream) in the BH vs. standardized wetland-stream distance in prairie potholes in ND. (b) Standardized wetland-wetland distance (observed shortest distances of wetlands to their nearest wetland neighbor) in the $\mathrm{BH}$ vs. standardized observed wetland-wetland distance in prairie potholes in ND.

icantly larger than the number of wetlands connected from surface pathways, even in response to large precipitation events (Fig. 5). Fast surface connections originated from the wetlands located near the river (with a maximum distance of $8 \mathrm{~km}$ ), whereas slow subsurface connections originated from a wide range of close and distant wetlands with a maximum distance of $30 \mathrm{~km}$ from the river. Indeed, model simulations reveal that regional surface waters integrate a wide range of continuum of time and length variations of connectivity, not just rapid or surface-connected flowpaths located at the top of this continuum.

Watershed hydrologic, biogeochemical and biological functions in wetland-dominated landscapes such as the Beaverhill watershed are influenced by the transit times, velocities (rates) and mode (pathways) of hydrologic connection (Bracken and Croke, 2007; Cohen et al., 2016). Wetlands that connect rapidly (but not persistently) to the river via surface fill-and-spill mechanism constrain peak flow volumes, delay peak timing and retain sediments (Craft and Casey, 2000). However, wetlands that connect to the river only via slower subsurface flowpaths regulate water table depth (Lane et al., 2015), maintain base flow and recession rate of river hydrographs (McLaughlin et al., 2014; Golden et al., 2015) and retain and transform pollutants (Marton et al., 2015). Our results show that as distance between wetlands and the North Saskatchewan River increases, connection time between wetlands and the river also increases (Fig. 8). Therefore, while the flow contribution from surface and subsurface connections is similar, the timescales at which the subsurface connections travel from source to river are much longer (i.e., the subsurface flow contribution represents water that may be much older). The long transit times of subsurface connections of distal wetlands may significantly impact biogeo- 
chemical processes in the vicinity of the river, improving water quality of regional water resources. For example, regional subsurface pathlines originating from distal wetlands can facilitate the completion of kinetically limited reactions and enhance retention, sorption and transformation of sorbing nutrients (Min et al., 2010), metals (Mays and Edwards, 2001) and likely pesticides (Ameli, 2016), all of which positively influence aquatic ecosystem structure and function (e.g., Euliss et al., 2004; Cook and Hauer, 2007). Figure 6c depicts the simulated cumulative probability of transit time distributions of water flowing from wetlands to the North Saskatchewan River (ensemble of surface and subsurface wetland-originated contributions) and summarizes the potential ecosystem services of each portion of this continuum.

\subsection{Distance not a proxy for connectivity}

Our results show that all wetlands located within a distance of $30 \mathrm{~km}$ can affect the quantity and quality of water in the North Saskatchewan River. Contrary to Hayashi et al. (2016), who hypothesized that wetlands in the PPR can only be connected to closely adjacent water bodies and that subsurface flow through the deeper portions is insignificant, our findings using novel 3-D watershed-scale subsurface-surface connectivity model corroborate the findings of Winter et al. (2003), who showed that distal sources can impact the quality and quantity of water in the regional surface water bodies in prairie pothole landscape in North Dakota. Quantification of the contribution of wetlands to the river suggests that slow subsurface flow contribution to the river flow is substantial $\left(0.775 \times 10^{6} \mathrm{~m}^{3}\right.$ per month $)$ and comparable to the surface flow contribution $\left(0.81 \times 10^{6} \mathrm{~m}^{3}\right.$ per month during the driest year and $1.43 \times 10^{6} \mathrm{~m}^{3}$ per month during the wettest year since 2000). In addition, although the surface flow contribution from wetlands to the river is correlated with the wetlands' distance to the river, subsurface flow contribution from wetlands to the river had a weak relationship with the distance between wetlands and the river (Fig. 8), and a broad range of proximal and distal wetlands can be connected to the river (Fig. 6a) and influence the river quality and quantity. This implies that decisions to protect GIWs based only on distance of the wetland to a river (e.g., 2015 US Clean Water Rule (Federal Register 80: 37054-37127)) may lead to the loss of distal wetlands with important watershed functions.

These findings can be extended to the entire PPR, since the climate, geology and topography can be considered almost (statistically) similar throughout the PPR. Although Fig. 9 suggests that the distribution of wetlands does not differ significantly between the Beaverhill watershed and the prairie pothole landscape in North Dakota, this figure shows a higher density of wetlands in the range of long distances among wetlands in North Dakota compared to the Beaverhill watershed (i.e., more distant wetlands are relatively closer to one another in North Dakota). The longer distances among wetlands in the Beaverhill watershed may imply a less fre- quent surface hydrologic connectivity among wetlands in the Beaverhill watershed compared to the North Dakota landscape.

\subsection{Guidelines for wetland protection, removal and restoration}

Human alteration has changed the natural continuum and timing of hydrologic connectivity (Min et al., 2010; Pringle, 2003). Given that the aforementioned ecosystem services accrue from a continuum of transit times, the cumulative impact of such alteration can be significant (Johnston, 1991; Zedler, 2003). Current wetland management strategies in the PPR are likely to lead to loss of wetlands (particularly GIWs) located far from regional surface waters (Van Meter and Basu, 2015; Serran and Creed, 2016). Removing these wetlands can increase surface pathways towards rivers with potential consequences of flooding and eutrophication during large events. For example, the loss of GIWs in watersheds including the Beaverhill watershed has been implicated as one cause of the increase in phosphorus loading to Lake Winnipeg, located $1300 \mathrm{~km}$ east of the Beaverhill watershed, leading to eutrophication events and the 2013 listing of Lake Winnipeg as the most threatened lake in the world (Ulrich et al., 2016).

\section{Conclusion}

A one-way linked subsurface-surface model was developed to assess the continuum of time and distance variations of hydrologic connectivity of wetlands in a large watershed with a high density of geographically isolated wetlands in the Prairie Pothole Region. The model showed that wetlands are not hydrologically isolated, and that the surface and subsurface hydrologic connections vary significantly in terms of their timing and length. Contributions of slow subsurface connections from both proximal and distal wetlands to the river are substantial and comparable to the contributions of fast surface connections.

The subsurface-surface model is computationally efficient, enabling upscaling to the entire Prairie Pothole Region (and elsewhere) to assess wetland connectivity that was heretofore difficult to quantify and providing guidance on the development of watershed management and conservation plans (e.g., wetlands drainage/restoration) under different climate and land management scenarios. Our modeling approach can explicitly assess and evaluate the hydrologic connectivity of individual wetlands, providing scientists and conservation authorities with information to understand and manage the potential response of the entire watershed to direct and indirect changes such as wetland drainage or restoration. We recommend coupling robust hydrologic connectivity models with biogeochemical and biological data which can (1) improve our understanding of landscape hydrologic 
connectivity and its impact on the structure and function of wetlands and (2) aid in the assessment of feedbacks between hydrology, biogeochemistry and biology.

Data availability. The data used in this paper are available upon request from the corresponding author. 
Appendix A: Mathematical formulation of the groundwater-surface water interaction model

At each layer $(m=1 \ldots M)$ of an unconfined aquifer, the exact 3-D series solution to the saturated steady flow governing equation, with no-flow conditions along the sides of the computational domain, was obtained in terms of discharge potential function $\left(\phi_{m}=K_{m} h_{s}\right)$ as (Ameli and Craig, 2014)

$$
\begin{aligned}
\phi_{m}(x, y, z) & =\sum_{j=0}^{J-1} \sum_{n=0}^{N-1} \cos \omega_{j} x \cos \omega_{n} y\left[A_{j n}^{m} \cos h\left(\gamma_{j n} z\right)\right. \\
& \left.+B_{j n}^{m} \sin h\left(\gamma_{j n} z\right)\right],
\end{aligned}
$$

where $\omega_{j}=\frac{j \pi}{L_{x}} ; \quad \omega_{n}=\frac{n \pi}{L_{y}} ; \quad \gamma_{j n}=\pi \sqrt{\frac{j^{2}}{L_{x}^{2}}+\frac{n^{2}}{L_{y}^{2}}}$ for $j=$ $0 \ldots J-1$ and $n=0 \ldots N-1$.

In Eq. (A1), $h_{s}(x y, z)$ is the total hydraulic head, and $K_{m}$ $\left(\mathrm{LT}^{-1}\right)$ is the $m$ th layer saturated hydraulic conductivity. In addition, $j$ and $n$ represent the coefficient index, whereas $J$ and $N$ refer to number of series in the $x$ and $y$ directions, respectively. A total of 144 series terms $(N=12$ and $J=12)$ were used. The series coefficients associated with the $m$ th layer and $j$ th and $n$th series term are $A_{j n}^{m}$ and $B_{j n}^{m}$. The rectangular computational domain with no-flow side boundaries has a length of $L_{x}=84.5 \mathrm{~km}$ and $L_{y}=95.4 \mathrm{~km}$ in $x$ and $y$ directions, respectively, which embeds the watershed boundary as shown in Fig. 1. No-flow side boundaries were placed at the sides of the computational domain, on average, $20 \mathrm{~km}$ away from the watershed original border; this treatment minimized the impact of side boundaries on flow behavior and subsurface connections. A continuous map of hydraulic head was then obtained as

$h_{s}(x, y, z)=\frac{\phi_{m}(x, y, z)}{K_{m}}$.

To complete the solution, the unknown series solution coefficients of each layer $\left(A_{j n}^{m}, B_{j n}^{m}\right)$ were calculated by imposing infiltration rate along the topographic surface, the no-flow condition along the bottom boundary and the continuity of flux and head conditions along the layer interface of the multilayer unconfined aquifer. A simple numerical least-square scheme was used to impose these boundary and continuity conditions. In general, this continuous solution (Eq. A1) exactly satisfies the mass balance and Darcy equations in the entire watershed, except along the boundaries where mass balance and Darcy equations are prone to numerical least-square error. Ameli and Craig (2014) showed that this error can be negligible when a sufficient number of control points were used within the numerical least-square algorithm. To ensure minimum numerical least-square error along the boundary and layer interfaces, 806130 control points (uniformly spaced at each $100 \mathrm{~m}$ ) were placed along two boundary interfaces and the layer interface of the computational domain.
The continuous maps of Darcy fluxes at the $m$ th layer and at each $x, y$ and $z$ direction can be computed by the following equation:

$q_{m}^{x}(x, y, z)=\frac{d \phi_{m}(x, y, z)}{\mathrm{d} x}$
$q_{m}^{y}(x, y, z)=\frac{d \phi_{m}(x, y, z)}{\mathrm{d} y}$
$q_{m}^{z}(x, y, z)=\frac{d \phi_{m}(x, y, z)}{\mathrm{d} z}$.

Equation (A3) can also be used to determine groundwater discharge fluxes at discharge areas (seepage faces) along the land surface as well as groundwater recharge fluxes where the water table is below the land surface. A subsurface map of pore water velocities $(V)$, which is required to perform subsurface water particle tracking, was obtained as

$V_{m}^{x}(x, y, z)=\frac{1}{\theta_{s}} q_{m}^{x}(x, y, z)$
$V_{m}^{y}(x, y, z)=\frac{1}{\theta_{s}} q_{m}^{y}(x, y, z)$
$V_{m}^{z}(x, y, z)=\frac{1}{\theta_{s}} q_{m}^{z}(x, y, z)$,

where $\theta_{s}$ is subsurface porosity. Inputs to the model included (1) the location and water level of wetlands and (2) material properties of the subsurface. For (1), the delineated wetlands explained in Sect. 2.2 were used, and we assumed that the water level was equal to the average elevation of each wetland boundary. This water level was used as a constant head boundary condition at each wetland. For (2), a two-layer unconfined aquifer with a $5 \mathrm{~m}$ thick shallow layer was used to characterize the subsurface (as suggested in van der Kamp and Hayashi, 2009). The bottom boundary of the computational domain was assumed to be at $Z=0$ with a no-flow condition. A porosity $\left(\theta_{S}\right)$ value of 0.14 equal to the average measured porosity at the Beaverhill watershed (Gleeson et al., 2014) was also used. 
Competing interests. The authors declare that they have no conflict of interest.

Acknowledgements. This research was funded by a NSERC Discovery Grant and an Alberta Land Institute Grant to IFC. The authors gratefully acknowledge Alberta Agriculture and Forestry, Alberta Environment and Parks, Alberta Geological Survey and Environment and Climate Change Canada for providing some of the data and measurements used in this paper. The authors would also like to thank Jeffrey McDonnell, Allan Rodhe, Kevin Bishop and Thomas Grabs for providing insightful comments which improved the quality of the manuscript.

Edited by: U. Ehret

Reviewed by: two anonymous referees

\section{References}

Ameli, A. A.: Controls on subsurface transport of sorbing contaminant, Hydrol. Res., doi:10.2166/nh.2016.170, 2016.

Ameli, A. A. and Craig, J. R.: Semianalytical series solutions for three-dimensional groundwater-surface water interaction, Water Resour. Res., 50, 3893-3906, doi:10.1002/2014WR015394, 2014.

Ameli, A. A., Amvrosiadi, N., Grabs, T., Laudon, H., Creed, I., McDonnell, J., and Bishop, K.: Hillslope permeability architecture controls on subsurface transit time distribution and flow paths, J. Hydrol., 543, 17-30, doi:10.1016/j.jhydrol.2016.04.071, 2016a.

Ameli, A. A., McDonnell , J. J., and Bishop, K.: The exponential decline in saturated hydraulic conductivity with depth and its effect on water flow paths and transit time distribution, Hydrolog. Process., 30, 2438-2450, doi:10.1002/hyp.10777, 2016b.

Ameli, A. A., Beven, K., Erlandsson, M., Creed, I., McDonnell, J., and Bishop, K.: Primary weathering rates, water transit times and concentration-discharge relations: A theoretical analysis for the critical zone, Water Resour. Res., 53, 942-960, doi:10.1002/2016WR019448, 2017.

Baatz, M. and Schäpe, A.: Multiresolution segmentation: an optimization approach for high quality multi-scale image segmentation, Angewandte Geographische Informationsverarbeitung XII, Karlsruhe, Germany, 12-23, 2000.

Barker, A., Riddell, J., Slattery, S., Andriashek, L., Moktan, H., Wallace, S., Lyster, S., Jean, G., Huff, G., and Stewart, S.: Edmonton-Calgary corridor groundwater atlas, Energy Resources Conservation Board, ERCB/AGS Information Series, 140, 90, 2011.

Bear, J.: Dynamics of fluids in porous media, Eisevier, New York, 764 pp., 1972.

Bracken, L. J. and Croke, J.: The concept of hydrological connectivity and its contribution to understanding runoff-dominated geomorphic systems, Hydrol. Process., 21, 1749-1763, 2007.

Brannen, R., Spence, C., and Ireson, A.: Influence of shallow groundwater-surface water interactions on the hydrological connectivity and water budget of a wetland complex, Hydrol. Process., 29, 3862-3877, 2015.

Bresciani, E., Gleeson, T., Goderniaux, P., de Dreuzy, J., Werner, A., Wörman, A., Zijl, W., and Batelaan, O.: Groundwater flow systems theory: research challenges beyond the specified-head top boundary condition, Hydrogeol. J., 24, 1087-1090, 2016.

Burns, D. A., Plummer, L. N., McDonnell, J. J., Busenberg, E., Casile, G. C., Kendall, C., Hooper, R. P., Freer, J. E., Peters, N. E., and Beven, K.: The geochemical evolution of riparian ground water in a forested piedmont catchment, Ground Water, 41, 913925, 2003.

Cohen, M. J., Creed, I. F., Alexander, L., Basu, N. B., Calhoun, A. J., Craft, C., D’Amico, E., DeKeyser, E., Fowler, L., and Golden, H. E.: Do geographically isolated wetlands influence landscape functions?, P. Natl. Acad. Sci. USA, 113, 1978-1986, 2016.

Cook, B. J. and Hauer, F. R.: Effects of hydrologic connectivity on water chemistry, soils, and vegetation structure and function in an intermontane depressional wetland landscape, Wetlands, 27, 719-738, 2007.

Craft, C. B. and Casey, W. P.: Sediment and nutrient accumulation in floodplain and depressional freshwater wetlands of Georgia, USA, Wetlands, 20, 323-332, 2000.

Dixon, M., Loh, J., Davidson, N., Beltrame, C., Freeman, R., and Walpole, M.: Tracking global change in ecosystem area: the Wetland Extent Trends index, Biol. Conserv., 193, 27-35, 2016.

Euliss, N. H., LaBaugh, J. W., Fredrickson, L. H., Mushet, D. M., Laubhan, M. K., Swanson, G. A., Winter, T. C., Rosenberry, D. O., and Nelson, R. D.: The wetland continuum: a conceptual framework for interpreting biological studies, Wetlands, 24, 448458, 2004.

Frei, S. and Fleckenstein, J. H.: Representing effects of microtopography on runoff generation and sub-surface flow patterns by using superficial rill/depression storage height variations, Environ. Modell. Soft., 52, 5-18, doi:10.1016/j.envsoft.2013.10.007, 2014.

Gleeson, T., Moosdorf, N., Hartmann, J., and Beek, L.: A glimpse beneath earth's surface: GLobal HYdrogeology MaPS (GLHYMPS) of permeability and porosity, Geophys. Res. Lett., 41, 3891-3898, 2014.

Godsey, S. E., Kirchner, J. W., and Clow, D. W.: Concentrationdischarge relationships reflect chemostatic characteristics of US catchments, Hydrol. Process., 23, 1844-1864, 2009.

Golden, H., Creed, I. F., Ali, G., Basu, N. B., Neff, B., Rains, M., McLaughlin, D., Alexander, L., Ameli, A. A., Christensen, J., Evenson, G., Jones, C., Lane, C., and Lang, M.: Scientific tools for integrating geographically isolated wetlands into land management decisions, Front. Ecol. Environ., accepted, 2017.

Golden, H. E., Lane, C. R., Amatya, D. M., Bandilla, K. W., Kiperwas, H. R., Knightes, C. D., and Ssegane, H.: Hydrologic connectivity between geographically isolated wetlands and surface water systems: a review of select modeling methods, Environ. Modell. Softw., 53, 190-206, 2014.

Golden, H. E., Sander, H. A., Lane, C. R., Zhao, C., Price, K., D'Amico, E., and Christensen, J. R.: Relative effects of geographically isolated wetlands on streamflow: a watershed-scale analysis, Ecohydrology, 9, 21-38, 2015.

Hayashi, M., van der Kamp, G., and Rosenberry, D. O.: Hydrology of prairie wetlands: understanding the integrated surface-water and groundwater processes, Wetlands, 36, 237-254, 2016.

Johnston, C. A.: Sediment and nutrient retention by freshwater wetlands: effects on surface water quality, Crit. Rev. Env. Sci. Tec., 21, 491-565, 1991. 
Kirchner, J. W.: Aggregation in environmental systems - Part 1: Seasonal tracer cycles quantify young water fractions, but not mean transit times, in spatially heterogeneous catchments, Hydrol. Earth Syst. Sci., 20, 279-297, doi:10.5194/hess-20-2792016, 2016.

Lane, C. R., Autrey, B., Jicha, T., Lehto, L., Elonen, C., and SeifertMonson, L.: Denitrification Potential in Geographically Isolated Wetlands of North Carolina and Florida, USA, Wetlands, 35, 459-471, 2015.

Leibowitz, S. G.: Isolated wetlands and their functions: an ecological perspective, Wetlands, 23, 517-531, 2003.

Leibowitz, S. G.: Geographically Isolated Wetlands: Why We Should Keep the Term, Wetlands, 35, 997-1003, 2015.

Leibowitz, S. G. and Vining, K. C.: Temporal connectivity in a prairie pothole complex, Wetlands, 23, 13-25, 2003.

Lindsay, J. B. and Creed, I. F.: Sensitivity of digital landscapes to artifact depressions in remotely-sensed DEMs, Photogramm. Eng. Rem. S., 71, 1029-1036, 2005.

Maher, K. and Druhan, J.: Relationships between the transit time of water and the fluxes of weathered elements through the critical zone, Procedia Earth and Planetary Science, 10, 16-22, 2014.

Manning, R.: On the flow of water in open channels and pipes, Transactions of the Institution of Civil Engineers of Ireland, 20, 161-207, 1891.

Marton, J. M., Creed, I. F., Lewis, D. B., Lane, C. R., Basu, N. B., Cohen, M. J., and Craft, C. B.: Geographically Isolated Wetlands are Important Biogeochemical Reactors on the Landscape, BioScience, 65, 408-418, 2015.

Mays, P. and Edwards, G.: Comparison of heavy metal accumulation in a natural wetland and constructed wetlands receiving acid mine drainage, Ecol. Eng., 16, 487-500, 2001.

McDonnell, J. J. and Beven, K.: Debates - The future of hydrological sciences: A (common) path forward? A call to action aimed at understanding velocities, celerities and residence time distributions of the headwater hydrograph, Water Resour. Res., 50, 5342-5350, 2014.

McGuire, K. J. and McDonnell, J. J.: A review and evaluation of catchment transit time modeling, J. Hydrol., 330, 543-563, 2006.

McLaughlin, D. L. and Cohen, M. J.: Realizing ecosystem services: wetland hydrologic function along a gradient of ecosystem condition, Ecol. Appl., 23, 1619-1631, 2013.

McLaughlin, D. L., Kaplan, D. A., and Cohen, M. J.: A significant nexus: Geographically isolated wetlands influence landscape hydrology, Water Resour. Res., 50, 7153-7166, 2014.

Min, J.-H., Perkins, D. B., and Jawitz, J. W.: Wetland-groundwater interactions in subtropical depressional wetlands, Wetlands, 30, 997-1006, 2010.

Morton, F. I.: Estimating evapotranspiration from potential evaporation: Practicability of an iconoclastic approach, J. Hydrol., 38, 1-32, 1978.

Mushet, D. M., Calhoun, A. J., Alexander, L. C., Cohen, M. J., DeKeyser, E. S., Fowler, L., Lane, C. R., Lang, M. W., Rains, M. C., and Walls, S. C.: Geographically isolated wetlands: rethinking a misnomer, Wetlands, 35, 423-431, 2015.

Pringle, C.: The need for a more predictive understanding of hydrologic connectivity, Aquat. Conserv., 13, 467-471, 2003.

Rains, M., Leibowitz, S., Cohen, M., Creed, I., Golden, H., Jawitz, J., Kalla, P., Lane, C., Lang, M., and McLaughlin, D.: Geograph- ically isolated wetlands are part of the hydrological landscape, Hydrol. Process., 30, 153-160, 2015.

Rains, M. C., Fogg, G. E., Harter, T., Dahlgren, R. A., and Williamson, R. J.: The role of perched aquifers in hydrological connectivity and biogeochemical processes in vernal pool landscapes, Central Valley, California, Hydrol. Process., 20, 11571175, 2006.

Salamon, P., Fernàndez-Garcia, D., and Gómez-Hernández, J. J.: A review and numerical assessment of the random walk particle tracking method, J. Contam. Hydrol., 87, 277-305, 2006.

Sass, G., Creed, I., Riddell, J., and Bayley, S.: Regional-scale mapping of groundwater discharge zones using thermal satellite imagery, Hydrol. Process., 28, 5662-5673, 2014.

Serran, J. and Creed, I.: New mapping techniques to estimate the preferential loss of small wetlands on prairie landscapes, Hydrol. Process., 30, 396-409, 2016.

Shaw, D. A., Vanderkamp, G., Conly, F. M., Pietroniro, A., and Martz, L.: The fill-spill hydrology of prairie wetland complexes during drought and deluge, Hydrol. Process., 26, 3147-3156, 2012.

Shook, K., Pomeroy, J. W., Spence, C., and Boychuk, L.: Storage dynamics simulations in prairie wetland hydrology models: Evaluation and parameterization, Hydrol. Process., 27, 1875-1889, 2013.

Shrestha, R. R., Dibike, Y. B., and Prowse, T. D.: Modeling climate change impacts on hydrology and nutrient loading in the upper assiniboine catchment, J. Am. Water Resour. As., 48, 7489, 2012.

Sturm, M., Taras, B., Liston, G. E., Derksen, C., Jonas, T., and Lea, J.: Estimating Snow Water Equivalent Using Snow Depth Data and Climate Classes, J. Hydrometeorol., 11, 1380-1394, doi:10.1175/2010JHM1202.1, 2010.

Therrien, R., McLaren, R., Sudicky, E., and Panday, S.: HydroGeoSphere: A three-dimensional numerical model describing fully-integrated subsurface and surface flow and solute transport, Groundwater Simul. Group, Waterloo, Ontario, Canada, 2008.

Tiner, R. W.: Estimated extent of geographically isolated wetlands in selected areas of the United States, Wetlands, 23, 636-652, 2003.

Ulrich, A. E., Malley, D. F., and Watts, P. D.: Lake Winnipeg basin: advocacy, challenges and progress for sustainable phosphorus and eutrophication control, Sci. Total Environ., 542, 1030-1039, 2016.

US-EPA: Connectivity of Streams and Wetlands to Downstream Waters: A Review and Synthesis of the Scientific Evidence (US Environmental Protection Agency, Washington, DC), 2015.

van der Kamp, G., and Hayashi, M.: Groundwater-wetland ecosystem interaction in the semiarid glaciated plains of North America, Hydrogeol. J., 17, 203-214, 2009.

Van Meter, K. J. and Basu, N. B.: Signatures of human impact: size distributions and spatial organization of wetlands in the Prairie Pothole landscape, Ecol. Appl., 25, 451-465, 2015.

Winter, T. C. and LaBaugh, J. W.: Hydrologic considerations in defining isolated wetlands, Wetlands, 23, 532-540, 2003.

Zedler, J. B.: Wetlands at your service: reducing impacts of agriculture at the watershed scale, Front. Ecol. Environ., 1, 65-72, 2003. 